\section{MEDICAL EDUCATION IN ITALY.}

By F. H. Burton-Brown, M.A., M.B., B.Ch.Oxon., Physician to the British Embassy in Kome; late Professor of Medicine Punjab University, and Physician to the Mayo Hospital, Lahore. The UnJversities AND THE STATE.

MeDical education in Italy is directly under the control of the Minister for Public Instruction, who is always a Cabinet Minister.

The degree of M.D. is granted by the Cniversities of Turin Pavia, Parma, Padua, Bologna, Florence, Siena, Pisa, Genoa, Rome, Naples, Palermo, and Cagliari. Certain others-for example, Perugia-give instruction in the preliminary subjects of the course of medical study, but no clinical instruction; and therefore a student who has passed his preliminary examinations at one of these has to betake himself for three years of clinical study to one of the "universities of the first rank" to obtain his M.D. This is the only qualification recognised by the Italian law for Italian medical men, and the universities which grant it are directly responsible to the Minister; they are nowise jndependent as regards the standard of their examinations or official courses. so that the standard of medical education is in theory remarkably uniform throughout Italy.

The Curriculty.

The academic zear lasts from the middle of October to the end of July. Of this period the first fortnight and the last six weeks are given over entirely to examinations; and there are as well vacations at Christmas and Easter of abnut a fortnight sach, so that the actual teaching year consists of about twenty-seven weeks. The period of study required by the law of the Italian medical student consists in six academic years, during which he has to attend courses in twenty-two subjects, and to pass examinations in these before he is admitted to the final examination or that for the M.D. These examinations may he passed in any order the student prefers so that a student who fails in any particular one is not thereby put out of his year; he goes on with his regular course of studies; he has merely to pay particular attention to the subject he has failed in, and to have another attempt at the end of the next year.

There are 22 examinations required. namely :

Zoology.

Comparative Anatomy and Pliysiology.

Botany.

Physics.

Histology.

Histology.

Human Anatomy.

Materia Medica.

General Pathology.

Pathological Anatomy.

Special Medical Pathology.

Secial Murical Pathology.

(The two Jatter subjects include the c'inical teaching of the physical examination, and also the clivical history, of disease, the technical term for which is " Propedeutics." "The professors engaged in teaching these have at nany universities wards of engaged in te

Surgical Avatomy and Practical operations.

Clinical Medicine.

Clinical Surgery.

Clinical Obstetrics.

Clinical Diserses of the Eye.

Clinical Mental Disease

Clinical Diseases of the Skin, and Syphilis.

Legal Medicine.

As a general rule the professors teaching the first five subjects belong to the Faculty of Natural Science, so that the Faculty of $M$-dicine and Surgery normally consists of 17 professors. In some of the smaller universities, however, there are only 14 or 15 professors, so that some have to teach in more than one subject: while in the larger there are generally more; the extra professors either take part in teaching one of the obligatory subjects, or else teach a subject an examination in which is not legally required; for example, diseases of nose and ear. The corresponding courses of instruction are, in general, annual, except that of pathological anatomy, which is always biennial; physiology, which is usually so; human anatomy, which is usually triennial clinical medicine and surgery, which are always triennial. Each professor has one or two assistant professors, one $n r$ two ordinary assistants, and many have a varying numb?r of extraordinary and honorary assistants.
THE M.D. DEGREE.

When the student has passed all of these examinations he may supplicate to be admitted to the final, or examination for the M.D., the "Laurea in Medicina e Chirurgia." This consists of a written and three oral theses, all of which are selected by him. The fees payable consist of 40 lire on matriculation. 127.67 lire annually, including 16.67 examination fees, and 60 for the M.D. diploma, in all about $£ 33$ Ios. These fees include admission to all the official courses.

OfFicial and “ Free" Lectures.

The university instruction includes, in addition, many nonofficial or free courses (which the student has to pay for). The official courses are given by the professor and his assistants. The free are given in some cases by the professors or their assistants, but in the majority of cases by the privat docents. Of the official courses, some are obligatory, while others are not, and such are termed complementary courses. Some of the free are legally equivalent to the official-that is, the student can be "signed up" for attending them instead of the corresponding official courses, while others again are complementary; the student is not, however, allowed to attend more than a certain number of free courses, usually only three in the year, and their hours must not interfere with any offlcial course.

Laboratories and Special Institutes.

During the last ten years a great impulse has been given to medical study in Italy by the building of fine and even magnificent institutions and laboratories at many of the universities. A good example is to be seen in the Policlinico at Rome, which will shortly be opened. The laboratories of the University of Turin are admirable examples of what can be done by united effort, the State; the University, and the Municipality having contributed to their cost in equal shares. Similar institutions are shortly to be erected at Bologna. Private munificence has also not been lacking. Thus the fine orthopædic insitution at Bologna was built out of funds bequeathed by a private individual. There is no doubt that England has much to learn from United Italy with regard to the endowment of research. A large amount of scientific work is done in the Italian university laboratories, and, judging from the number of memoirs issued from them, much of it of very high quality. Considering the comparative poverty of the country, too high praise can scarcely be given to the modern development of medical research in Italy. The laboratories and clinics are little frequented by English and American post-graduate students, but they certainly present great facilities for research.

The various universities which grant the degree of M.D. may now be considered seriatim from the point of view of the instruction given to the student.

\section{Torin.}

The number of medical stucients at the University of Turin in 1900.01 was 793, of whom 9 were women. There are 15 professors; the professor of surgery also teaches operative surgery and surgical pathology, the professor of clinical mental diseases also teach es legal medicine, the professor of anatomy teaches histology, and there are two extra chairs for diseases of ear, nose, and throat, and parasitology respectively. There are 66 privat-docents.

The course of study is as follows:

First Year-Physics, Botany, Zoology, Comparative Anatomy and Physiology. Human Anatomy and Histology, Dissection (every day from I P.M. to 9 P.M.).

Second Year.-Chemistry. Human Physiology, Human Anatomy and Histology, Dissections (as before).

Third Year.-Human Physiology, Practical Physiology, General Pathologi, Materia Medica and Pharmacology.

Fourth Year.-Clinical Surgery, Special Medical Pathology, Practical Medical Pathology, Special surgical Pathology, Pathological Anatomy. Fifth Year. - Operative Surgery (practical classes), Surgical Anatomy Hygiene, Practical Hygiene, Clinical Diseases of the Eye, Clinical Mediciue, Technique of Post-mortem Examinations, Clinical Surgery and Operations.

Sixth Year.-Legal Medicine, Clinical Medicine, Clinical Surgery and Operations, Obstetrics (lectures and practical classes). Clinical Mental Diseases, Venereal Diseases (clinical, winter session), Clinical Diseases of the Skin (summer session).

The Faculty recommends the student to take the examinations in the following order:

First Year.-Zoology, Comparative Anatomy. and Physiology, Physics, Botany. 
Second Year.-Chemistry.

Third Year. Human Anatomy, Human_Physiology, General Pathology, Materia Medica.

Fourth Year.-Medical Pathology, Surgical Pathology, Pathological Anatomy.

Fifth Year.-Surgical Anatomy, Practical Operations, Technique of Postmortem Examinations, Diseases of the Eye, Hygiene.

Sixth Year.-Legal Medicine, Clinical Diseases of Skin and Syphilis, inical Mental Diseases, Obstetrics, Clinical Medicine, Clinical Surgery.

In the examinations of the first three years 25 per cent. failed, and about 12 per cent. in those of the last three; of 120 candidates for the Final all passed.

The University possesses a fine set of Biological Institutes, which were opened in 1898 , the State, the University, and the Municipality contributing to their cost in equal shares. They are contained in four large blocks, facing the Park, and comprise the Institutes of Physiology, Human Anatomy, Chemistry, Physics, Pharmuceutical Chemistry and Toxicology, Materia Medica, Hygiene, Legal Medicine and Psychology, Pathological Anatomy, General Pathology.

These Institutes are contained in admirable buildings, very completely equipped. They comprise each a splendid lecture theatre, fitted for every method of demonstration, workrooms, museums, and examination room for students, and very complete research rooms and library for the professor (director) and his assistants. There are also rooms for the preparation of specimens, vivaria, etc. In fact the buildings and their equipment are so perfect that it is difficult to criticise them, except in a few small points. Thus the room for practical physiology for students is comparatively small, it is only adapted for small classes, and it is only in small classes that the student is taught. Thorein lies the essential difference between : the Italian system and the English : the student is taught admirably, and the demonstrations are as completely illustrated as is possible for: any to be ; specimens, diagrams, lantern exhibitions, experiments, etc., but the student does comparatively little practical work on his own initiative, except in private classes, which he is not bound to attend. This is also the German method, and on the Continent it is generally considered to be better adapted to the needs of the student than the English. It is not the place here to enter into a discussion of this wide question : it is sufficient to point out that it enables the demonstrator to cover a wider field of illustration, and this is particularly facilitated by the greater licence in demonstration experiments than is permitted in England, and at the same time on his part it permits of more time being spent in original research. On the other hand it is certainly deficient in that element of precision in observation which can only be attained by practical work by the student himself under the guidance of teachers, a system which requires much more individual teaching.

The same difference in systems is also to be observed on the clinical side, the student is trained to examine patients with the utmost care, but actually examines them for himself and on his own responsibility very little. The system of ward or house appointments is practically unknown.

The Anatomical Institute comprises, besides the general features already alluded to, a fine dissecting room, with a practically unlimited supply of subjects; a fine anatomical museum, divided into two parts, one comprising a very complete set of wax models, dry and wet dissections prepared bones, etc., for the use of students, and another containing in five large rooms material for research-rooms for practical histology, one for the official, another for private classes, room for practical anthropometry, and rooms for the preparation of subjects, etc. The instruction given comprises lectures four days a week for three years, daily dissections for the same time, a course in practical histology during one year, and special classes given by the assistant professor, and the assistants; forty "parts" are dissected by the student during the course of study.

The Physiological Institute contains a splendid set of research rooms, and the necessary workshops, vivaria, \&c. There is also a ronm for practical physiology for the students. The instruction given comprises a course of lectures three days a week for two years, and a practical course three days a week for one year.

General Pathology has a very completely-equipped set of research rooms. The instruction comprises a set of lectures three days a week for one year.

Pathological Anatomy has a very good and well ventilated post-mortem theatre, a large room for practical microscopy, a large museum, and complete set of rooms for research, including a large post-mortem room. The instruction comprises a course of lectures and demonstrations for one year three days a week, and during another year a practical course two days a week of pathological histology and technique of postnortem examinations.

Hygiene has a very complete museum, and a large room for practical work, well equipped for chemical and microscopic work. Here lectures and demonstrations are given three days a week for one year, and a practical course of one afternoon a week for one year.

Legal Medicine possesses a very interesting collection made by Professor Lombroso of wax models of the faces, ears, hands, etc., of numerous criminals, and also their skeletons, with the notes relating thereto. One room is full of the "tools of their trade"; two others contain various objects made in prison, sketches scratched on earthenware vessels, and many very extraordinary objects bearing on the psychology of the criminal. The instruction comprises lectures three times a week for one year.

Surgical Anatomy and practical operations comprises lectures given in the Anatomical Institute twice a week during one year, a course of practical operations every day from I P.M. to 9 P.M. during one year in a large room in the same place, and a course of lectures on topographical anatomy twice a week during one year (by the Professor of Anatomy).

The Institutes of Physics, Chemistry, Comparative Anatomy, and Materia Medica give official instruction in annual courses of lectures; but private classes are also held in each for those students who desire to do practical work.

In Botany practical instruction is given two days a week for first year students, and also lectures three days a week.

Clinical Instruction.-At the great city Hospital of S. Giovanni, originally founded in the twelfth century (much of the present building dating from the rebuilding in 1680), especial wards are set aside for clinical teaching by the professors of clinical medicine, clinical surgery, special clinical medical pathology, and "propedeutics," special clinical surgical pathology and "propedeutics," and diseases of the ear, nose, and throat. The first two have two wards each of 45 beds, the last three one ward of 40 beds each. There are also newly-built and very completely equipped clinical laboratories for the use of each professor, as well as a clinical museum, photographic and $x$-ray rooms, post-mortem theatre, vivaria, etc. The lecture and operating theatres are old, and shortly to be rebuilt, as is also the library.

The course of instruction comprises on the part of the professors of surgical and medical "propedeutics" an annual course of clinical instruction in physical examination as well as practical work in the lahoratory for three days a week. Special classes are also held in medical pathology, in the post-mortem theatre, and muspum. A triennial course of clinical lectures is given by the Professor of Medicine, five days a week, and instruction in the wards is given during this time by him and his assistants. The assistants also give special instruction in clusses in the wards and practical classes in the clinical laboratories, and instruction at outpatients is given every day.

A biennial course of clinical lectures is given by the Professor of Surgery on three days a week. Operations are usually performed on one day a week, and special courses of minor surgery are given by the assistants.

Ward work and instruction at nut-patients are carried on every day at the S. Giovanni Hospital under the supervision of the Professor and his assistants. The Professor of Surgery also gives instruction at the Ospedale Mauriziano, a foundation of the House of Savoy dating from the sixteenth century, but entirely rebuilt in 1887 . This is a very complete institution, arranged on the pavilion principle, with $\mathbf{a}$ good lecture theatre, two large operating ronms (one reserved for laparotomies), clinical laboratories, post mortem rooms, and vivaria. The number of beds availahle for clinical teaching is 160 . Here the Professor of Surgery lectures three days a week; operations are performed on one or two days, and also there are held special classes by the assistants every day.

Instruction in diseases of the ear, nose and throat is given as a complementary course, and consists of lectures during one year, two days a week, and instruction in the wards and 
classes in the clinical laboratories, on usually two other days.

The beds used for clinical teaching at the S. Giovanni Hospital are selected from all admitted into the hospital, and the teaching is only carried on during the academic year, the wards reverting to the ordinary uses of the hospital for the other months. At the Mauriziano bedside instruction is given all through the year.

The Eye Hospital is very well arranged and equipped, chiefly owing to Professor Reymond's exertions; the instruction given here comprises an annual course of lectures, operations, and practical classes on thrce mornings a week.

The Lying in Hospital and Gynocological Institute is modern, and an immense amount of work is done here. About 1,400 labours are attended during the year. The instruction comprises an annual course of lectures three days a week, work in the wards three other days, and practical classes. Instruction is given also at gynæcological out-patients and operations.

Mental Diseases. - Professor Lombroso gives an annual course of lectures on mental diseases at the asylum on three afternoons a week, and practical classes are taken in the laboratories.

Diseases of the Skin.-Clinical lectures are given at the clinic three days a week during the first half of the year as an annual course. During the second half year a corresponding course of clinical lectures is given at the clinic for syphilis.

Complementary Courses given by the professors include lectures, clinical chemistry, parasitology, and bacteriology. These are usually well attended. The courses given by privat-docents are forty in number, and include such courses as physiological chemistry and physics by Professor Mosso, clinical diseases of children at the children's hospital, orthopædics at the Maria Vittoria Hospital, a hospital for women and children, applied hygienic chemistry at the municipal laboratories, medical electricity, and other special courses. These are as a whole well attended by students, and, in fact, form no small part of their medical education.

(To be continued.)

\section{NOVA ET VETERA.}

ST. BARTHOLOMEW'S AND CHRIST'S HOSPITALS. IT may not be altogether unprofitable to retell the story of these great charities at a time when the removal of the one is causing a crisis in the history of the other.

St. Bartholomew's Hospital owes its foundation to Rahere, a knightly minstrel of the Court of Henry Beauclerc. Tradition tells that Rahere lay sick unto death. In a vision of the night a man of unearthly beauty and majesty came and stood by him, and said, " Rahere, I am Bartholomew the Apostle of Jesus Christ. Build in my name a holy house of God in Smithfield by London, and, lo! I will help thee." The sickness of Rahere passed away, and the minstrel devoted his life to the building of the stately church, over which he ruled as prior for 20 years, and close by it he placed the great hospital now known throughout the world. The buildings were begun in the year 1123, when it is said of Smithfield that

Right unelean it was, and, as a marsh, dungy and fenny, with water almost everywhere abounding; and that that was eminent above the water dry was deputed and ordained to the gibbet and gallows of thieves and to the torment of others that were condemned by judicial authority.
The place lay without the city wall, and yet was within the liberties of London. This site the hospital has always occupied, and there has always been the main entrance from Smithfield and the smaller gate into Little Britain, though other gates have from time to time been opened and again closed.

The hospital was at first smaller than that of the present day, and consisted of separate buildings clustered round a great hall, in which were probably most of the beds. "The great hall had a large fireplace in the middle, and King Henry III made a present to the hospital on September 1 ith, 1223, and again in 1224," says Dr. Norman Moore, "in these teims :

The King to Engelard de Cijoyny, greeting. We command you to give one old oak in our forest of Windsor on the Thames, with the lesst pos- sible injury to our forest and the greatest use to the aforesaid patients for their bearth.

Scattered amongst the hospital buildings were several chapels, with lodgings for their chaplains. One only of these chapels. is now left, and it forms the parish church of St. Bartholomew the I.ess. A part of its tower dates from before the year 1300 , and in the open space between it and the present great hall died Wat Tyler when he had been stabbed in the neck in Smithfield by William Walworth, Mayor, on Saturday morning, June 15 th, I38I. It was for this deed, it is said, that the dagger was added to the arms of the City of London. Around the hospital there were also many private houses, some of which had large gardens even as late as the times of Vicary and Harvey. The original hospital had eight brethren and four sisters, who elected a head called the Master, Proctor, orWarden. All swore obedience to the Prior and Canons of St. Bartholomew's Church, and the Master of the Hospital rendered an account twice a year of all receipts and expenditure. in the presence of the Bishop of London and of the Prior. Four times in the year too, all the brethren and sisters of the: hospital house came to the general assembly of the members. of the foundation of St. Bartholomew.

The hospital soon became popular among the citizens, and received many gifts of money and land, whilst it acquired a. right of sanctuary or freedom from arrest for those within its precincts. In 1536 its possessions were surrendered into the hands of Henry VIII, and the hospital was derelict for two years. But in the winter of 1538 the citizens of London petitioned the king to give them the vacant hospital then valued at $£_{304}$ 16s. 5 d. or $£_{35}$ 5s. $7 \mathrm{~d}$., yearly, the church remaining as a parish church for the inmates. It was not untilJune 23rd, I 544 , that letters patent were issued which declared the King's will that there should be " comfort to the prisoners, shelter to the poor, visitation to the sick, food to the hungry, drink to the thirsty, clothes to the naked, and sepulture to the dead. He therefore erected and founded a hospital to consist of one master and priest, and four chaplain-priests, to be called vice-master, the curate, the hospitaler, and the visitor of the prisoners in Newgate. No endowment was given by these letters patent, or "only so much as would maintain three or. four patients at most, and hardly that if cleanliness was regarded." The citizens continued to petition the King, Sir Richard Gresham, father of Sir Thomas Gresham, being particularly active in the matter, until in 1546 a new charter was granted to the Corporation of the City of London by which the hospital was refounded for the reception of 100 poor and sick. It was endowed from its former possessions to the extent of 500 marks per annum upon condition that the citizens should be bound yearly for ever to give a like sum. An attempt was made at this time to rechristen the hospital as "The House of the Poor in West Smithfield, near London, of the Foundation of King Henry VIII," but the older name was too well established to allow of any change though patients are still asked if they wish to be admitted into the " House."

The hospital was governed as a separate institution for about ten years, but in 1557 it was agreed to associate it with the rest of the royal hospitals, namely, Christ's Hospital, Bridewell, and St. Thomas's Hospital, the whole being under a comptroller-general and surveyor-general, while for each of the four was appointed for its special government four aldermen and eight commoners selected by the Lord Mayor and Court of Aldermen. Each member of this governing body held office for two years, the senior of the four aldermen being called the President and one of the commoners the Treasurer. This method of government did not prove entirely successful, and by the year 1666 the management of the affairs of the hospital had passed into the hands of a body of Governors, elected, as is still the case, either for their benefactions or for their services to the institution. Each Governor receives at his election a green staff of office, in shape like a billiard cue, with white letters upon it, the family colours, it is believed, of the house of Tudor, to whom the hospital owed both its destruction and its nominal refoundation.

In 1782 the government of St. Bartholomew's Hospital was separated from that of the other royal hospitals, and in 1866 it was decided that persons other than the Lord Mayor might be elected to the office of President. His Royal Highness Albert Edward Prince of Wales was chosen on this occasion, 